DOI

\title{
МЕТОДОЛОГІЧНІ АСПЕКТИ ПРОВЕДЕННЯ СТУДЕНТСЬКОЇ ПРЕДМЕТНОЇ ОЛІМПІАДИ З ДИСЦИПЛІНИ “ВНУТРІШНЯ МЕДИЦИНА”
}

\author{
І. П. Вакалюк, Н. М. Середюк, В. Н. Середюк, Р. В. Деніна, Т. В. Мергель \\ ДВНЗ “Івано-Франківський національний медичний університет”

\section{METHODOLOGICAL ASPECTS OF STUDENTS' OLYMPIAD ON DISCIPLINE “INTERNAL MEDICINE”} \\ I. P. Vakalyuk, N. M. Seredyuk, V. N. Seredyuk, R. V. Denina, T. V. Merhel \\ SHEI "Ivano-Frankivsk National Medical University"
}

\begin{abstract}
У статті розглянуто особливості організації та проведення олімпійських змагань студентів вищих медичних навчальних закладів, зокрема з навчальної дисципліни “Внутрішня медицина”. Авторами сформульована методика проведення олімпіади, яка включає в себе проведення тестового контролю, роботи біля ліжка хворого та вирішення ситуаційних задач підвищеної складності.
\end{abstract}

The article discusses features of organization and holding of Olympic competition of students in higher education institutions, including discipline "Internal medicine". The authors formulated methods of competition, which includes a control test, work at the bedside and solving situational problems of high complexity.

Вступ. Відповідно до Закону України “Про вищу освіту” головними завданнями наукової діяльності у вищому навчальному закладі є впровадження стандартів вищої освіти, підготовка та видання підручників і навчальних посібників 3 урахуванням інноваційних досягнень науки й техніки; впровадження результатів наукових досягнень у практику; безпосередня участь студентів у наукових розробках, що проводяться у вищому навчальному закладі; організація наукових, науково-практичних, науково-методичних семінарів, конференцій, олімпіад, конкурсів науково-дослідних, курсових, дипломних та інших робіт студентів вищих навчальних закладів [2]. Найбільш ефективною формою стимуляції професійного росту студентів $є$ участь майбутніх фахівців у предметних олімпіадах.

Основна частина. Олімпіада - це серйозна школа творчих змагань інтелекту, що надає студентам можливості перевірити свої знання та вміння, продемонструвати прагнення до наукового пізнання, клінічного мислення, оцінити якість різних методик навчання. До того ж олімпіада містить у собі елементи не лише навчального, але й дослідницького характеру. Крім виявлення талановитих студентів і формування в них інтересу до

(ㄱ І. П. Вакалюк, Н. М. Середюк, В. Н. Середюк та ін. наукової роботи з обраної спеціальності, олімпіада розвиває у студентів креативні здібності, формує активну життєву позицію $[1,3]$.

Випускник медичного вузу повинен не просто мати набір знань і вмінь, а бути готовим застосувати їх у житті. Чим вища професійна компетентність студентів і випускників, тим вища конкурентоспроможність вузу, і тому завдання його керівництва - організувати навчально-дослідницьку й наукову працю так, щоб студенти одержували найбільш важливі знання й навички, які допоможуть їм підтримувати належний рівень їх професійної майстерності [3, 4].

Олімпіада - це співпраця вузів і науковців, пошук найоптимальнішим шляхом як підвищення рівня навченості, так і вирішення наукових проблем конкретної галузі медицини, зокрема терапії. Це стосується не лише організації, а й самого змісту: під час олімпіади на обговорення присутніх виносять цікаві актуальні питання 3 медичної практики, рішення щодо яких приймається колегіально.

Розглядаючи предметну олімпіаду як складову, що виходить за рамки стандарту освітнього процесу, варто відзначити ті додаткові ефекти, які відсутні в традиційних формах навчального процесу та наукової діяльності студентства. До таких ефектів можна віднести: 
- мотивацію студентів до вивчення додаткових матеріалів, не охоплених навчальною програмою, у процесі підготовки до олімпіади й участі в ній;

- можливість самооцінки професійного рівня порівняно з рівнем інших учасників олімпіади;

- можливість зарекомендувати себе перспективними фахівцями.

Проведення олімпіад на високому організаційному рівні вимагає досить серйозної підготовки. До теперішнього часу у вищих навчальних закладах нагромаджено достатній досвід такої роботи. Однак питання, що стосуються методики проведення студентських предметних олімпіад, опрацьовано недостатньо. Серед вимог, що висовуються до методичного й організаційного забезпечення олімпіад, слід вважати такі, як: відкритість і доступність, рівність учасників, рівноцінність конкурсних завдань, ясність і якість оцінювання, наявність в учасників достатнього набору знань, умінь і практичних навичок [3, 4].

Олімпіада допомагає розв’язати такі завдання:

- виявити обсяг знань студентів у пізнавальній діяльності відповідно до категорій навчальних цілей (наприклад, знання, розуміння, застосування, аналіз, синтез, оцінка);

- виявити орієнтації студентів в активізації знань;

- встановити причини певного рівня навченості студентів.

Одним із завдань проведення олімпіад є якісна й об’ єктивна оцінка вирішених учасниками завдань. Перевіркою та оцінюванням знань займається журі. В обов’язки журі входять наступні функції: перевірка та оцінювання завдань, визначення переможців та оголошення результатів, підготовка відповідної документації, розгляд апеляційних справ та нагородження переможців. При проведенні олімпіади важливо, щоб члени журі не були розробниками завдань олімпіади (тестів, ситуаційних задач тощо), а лише організаційним та відповідальним органом. Тому в склад журі доцільно включати науково-педагогічних працівників вузів (докторів наук, професорів) з інших навчальних закладів.

Крім того, досить важливим є включення до програми олімпіади оригінальних номінацій (вміння спілкуватись із пацієнтом, глибокі знання сучасних стандартів ведення пацієнтів, краще виконання мануальних навиків, оперативне вирішення тестових завдань, чітке формулювання діагнозу, креативне клінічне мислення).

На перших курсах студентські олімпіади частіше проходять як перевірка індивідуального багажу знань із фундаментальних дисциплін. На старших курсах форма змагань наближається до моделі майбутньої роботи лікаря-фахівця.

Кожен з учасників-старшокурсників має можливість виявити свої найсильніші сторони і досягти певного успіху - перемоги. Від студента-учасника вимагається синтез знань, отриманих не тільки за роки вивчення внутрішньої медицини, але й суміжних дисциплін, таких, як фармакологія, інфекційні захворювання, лабораторна та променева діагностика. Особливе місце у підготовці олімпійця 3 внутрішньої медицини займають пропедевтика та деонтологія, вміння застосування стандартів семіотики при роботі з реальним хворим.

Історія проведення олімпіад показує, що одним 3 найбільш коректних способів оцінки теоретичних знань студента $є$ тестування за правилами державного ліцензійного іспиту “Крок-2”.

Тестовий контроль як перший етап олімпіади дає можливість виявити знання кожного учасника, простежити тенденції в навчальному процесі, виявити переваги та недоліки в опануванні певних розділів внутрішньої медицини.

Другим етапом проведення студентської олімпіади 3 внутрішньої медицини є курація хворих. Даний етап дає можливість виявити вміння використання студентом фізикальних методів обстеження хворих (огляд, перкусія, пальпація, аускультація). Терапевт перш за все повинен працювати органами чуття (зір, руки, вуха), а вже опісля користуватися додатковими лабораторними та інструментальними методами обстеження. Робота олімпійця біля ліжка хворого дає йому можливість ознайомитися з повним спектром терапевтичної патології в реальних умовах. Робота на цьому етапі виділяє різні методичні підходи щодо обстеження, тактики лікування, прийнятих різними терапевтичними школами, але й разом з тим вимагає виокремлення найважливіших рекомендацій, яких слід дотримуватися сучасному лікарю-практику.

На цьому етапі олімпіади оцінюються вміння збирання скарг; з'ясовувати анамнез захворювання та життя; методично правильно проводити огляд хворого та оцінювати загальний стан; здійснювати фізикальне обстеження серцево-судинної системи, органів дихання та черевної порожнини, кістковом’язової системи. Спеціально оцінюється вміння виокремлювати провідний синдром, складати план обстеження, інтерпретувати результати лабораторних та інструментальних методів дослідження, проводити диференційну діагностику, встановити попередній клінічний діагноз, визначати найбільш 
оптимальну та ефективну тактику ведення хворого. Саме у такий спосіб учасник олімпіади може продемонструвати свої вміння з пропедевтики внутрішніх захворювань, вміння виділяти провідний синдром, узагальнювати їх, поєднувати з анамнезом і в кінці встановлювати клінічний діагноз.

Клінічна дискусія з опонентами (іншими олімпійцями, членами журі) на даному етапі є одним із шляхів поглибленого клінічного мислення, вміння швидко і точно виділяти головні та другорядні ознаки захворювання, знаходити належний комплайнс із хворим, проявити індивідуальні риси характеру.

Важливим та цікавим етапом проведення олімпіади з внутрішньої медицини є вирішення ситуаційних задач (клінічних випадків із практики) підвищеної складності.

Ситуаційна задача являє собою конкретний клінічний випадок із практики професора кафедри, яка викладається стисло, але містить необхідну кількість інформації для встановлення діагнозу невідкладного стану та можливості ефективно допомогти хворому. Виходячи з умов задачі, учасник олімпіади повинен сформулювати також перелік діагностичних (інструментальних, лабораторних) методів для уточнення діагнозу, представити свою тактику надання невідкладної допомоги на основі стандартів медикаментозної терапії.

Ситуаційна задача містить в собі умову (відоме), вимогу (цілі) й пошук (невідоме), що формулюється в питанні. Розв’язання ситуаційних задач дає можливість студенту проявити знання із суміжних дисциплін, виділити провідний синдром, провести диференційну діагностику, застосувати максимально раціональну лікарську терапію у конкретного хворого на основі даних доказової медицини, вибрати найбільш ефективні та безпечні лікарські засоби. Рішення задач як процес подолання закладених у них протиріч створює оптимальні умови для розумового напруження, що і стає рушійною силою в розвитку клінічного мислення та вмінь учасника - найбільш важливих компонентів моделі сучасного фахівця.

Для прикладу наводимо ситуаційну задачу з варіантом відповіді.

Ситуаційна задача 1. Хвора К., 34 роки, знаходиться на лікуванні у кардіологічному стаціонарі 3 приводу артеріальної гіпертензї (АГ). Зі слів хворої, АГ спостерігається з дитинства, антигіпертензивні засоби не ефективні. АГ 160-180/90-96 мм рт. ст. Народила 2-х дочок (8 і 4 роки).

Об’єктивно: добре розвинутий верхній плечовий пояс, посилена пульсація сонних артерій, в легенях
- везикулярне дихання, пульс на стегнових артеріях ослаблений. Тони серця ритмічні, ЧСС - 72 уд/хв, мезосистолічний шум уздовж лівого краю груднини, на сонних артеріях та в міжлопатковій зоні.

На екрані: МРТ аорти хворої К. (рис. 1).

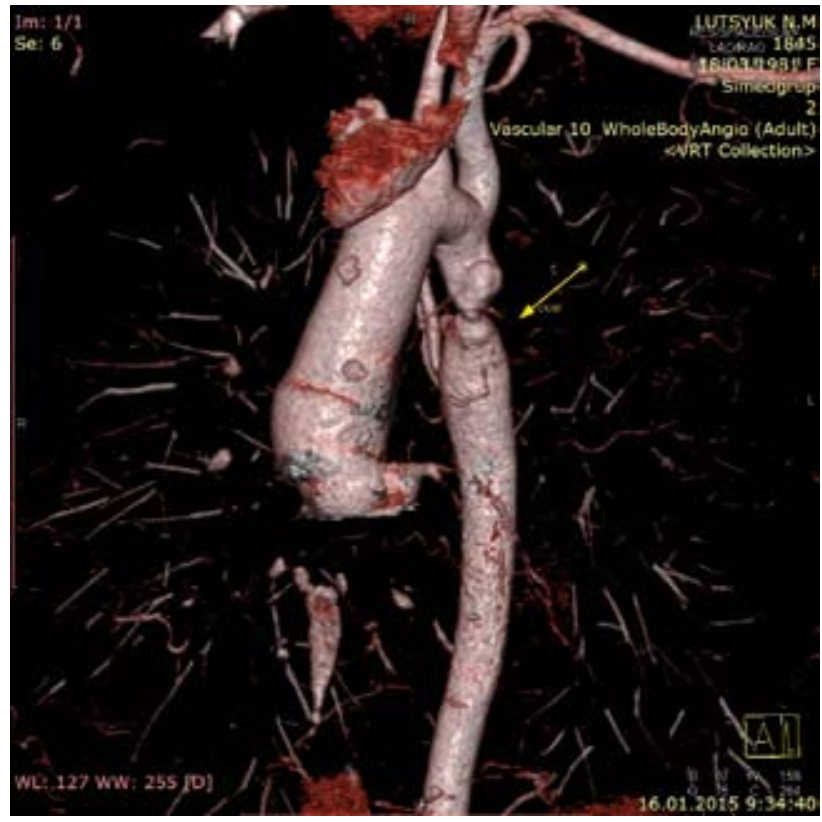

Рис. 1. МРТ аорти хворої K.

1. Який найбільш ймовірний діагноз у хворої К.?

2. Які діагностичні процедури слід використати з метою уточнення діагнозу?

3. Ваші рекомендації щодо подальшого ведення хворої?

Еталони відповіді.

1. Діагноз: Вроджена вада серця: коарктація аорти. Вторинна симптомна артеріальна гіпертензія II стадія, II ступінь, ризик 3.

2. Комп’ютерна томографія з контрастуванням або магніторезонансна томографія.

3. Рекомендації щодо подальшого ведення хворої K.

Скерування в Центр серця МО3 України або в Національний інститут серцево-судинної хірургії імені М. М. Амосова НАМН України для хірургічної корекції коарктації аорти.

Контроль артеріального тиску (АТ <140/90 мм рт. ст.), лізиноприл (5 мг 2 р/д), бісопролол (2,5 мг $1 \mathrm{p} / д)$, індапамід (2,5 мг 1 р/д).

Висновки. Таким чином, студентська олімпіада має такі функції: стимулюючу, навчальну, контролюючу, представницьку, “адаптаційну” (пристосування майбутніх спеціалістів до складних динамічних взаємодій як у процесі навчання, так і у майбутній професійній діяльності) . 
Проведення предметної олімпіади з внутрішньої медицини є важливим етапом у підготовці висококваліфікованих спеціалістів, ефективним способом набування нових практичних знань, навичок, демонстрація вмінь самовдосконалення.

Висновки і аналіз знань та навичок студентів дозволять викладачам акцентувати увагу на обговоренні проблемних питань внутрішньої медицини та у

\section{Список літератури}

1. Береснев А. Д. Система требований к методическому, программному и организационному обеспечению Интернет-олимпиад [Электронный ресурс] / А. Д. Береснев // Материалы Х Всероссийской научнометодической конференции “Телематика'2003”. - Режим доступа : http://www.ict.edu.ru.

2. Закон України “Про вищу освіту” (Закон від 01.07.2014 p. № 1556-VII). вирішенні складних завдань, що забезпечить у підсумку підвищення якості викладання дисципліни.

Окрім традиційних етапів олімпіади з внутрішньої медицини, що включає тестовий контроль за правилами державного ліцензійного іспиту “Крок-2” і роботу олімпійця біля ліжка хворого, ефективним та динамічним є етап-“бліц” з діагностики невідкладного стану та оцінки відеосюжету за його мотивами.

3. Ковальчук В. В. Основи наукових досліджень : навч. посіб. / В. В. Ковальчук, Л. М. Моїсеєв. - 3-тє вид., переробл. і доповн. - К. : ВД “Професіонал”, 2005. 240 c.

4. Лузік Е. В. Організація наукової діяльності студентів вищих навчальних закладів / Е. В. Лузік // Педагогіка і психологія професійної освіти: результати досліджень і перспективи : зб. наук. праць / за ред. І. А. Зязюна та Н. Г. Ничкало. - К., 2003. - С. 380-395. 